\title{
Celebrity in the Contemporary Era
}

Hannah Hamad

\begin{abstract}
What we may be looking at in more recent times is a redefining of what a celebrity actually is. It's not a Hollywood star necessarily. It's a hairdresser from Essex who's been on television.'

Ian Drury, Celebrity Publisher, Starsuckers (dir. Chris Atkins, 2009)
\end{abstract}

In 2012, pop star and celebrity style icon Lady Gaga capitalised on the cultural currency of twenty-first century celebrity by bottling fame and selling it. Literally. In August of that year, the Italian American singer and performance artist (known independently of her celebrity persona as Stefani Germanotta) launched her first fragrance 'Lady Gaga Fame' in the global fragrance market. It sold big, it sold fast, and it was enormously profitable to its stakeholders. As Lee Barron notes, 'Lady Gaga Fame' "reportedly sold six million bottles in its first week of release." (2015, 60) This example is instructive for understanding some of the dominant operational logics and industrial mechanics of contemporary celebrity in various ways and for a number of reasons.

The concept itself (i.e. the idea that fame can be bottled and sold) speaks directly to the longstanding Marxist cultural studies notion of 'standardisation' - the idea, foundationally theorised by Theodor Adorno, that popular cultural products can serve capitalism most profitably when they are reduced to simple formulae that 
are replicated and re-introduced to the mass market with slight variation that produces the illusion of differentiation for the consuming audience. Adorno elucidates this phenomenon most famously in relation to the commonalities and simplicities in chord structure and lyric that he identified in popular music recordings (1990 [1941]). But, writing in conjunction with Max Horkheimer, Adorno conceptually developed the phenomenon of standardisation to account for the embodied nature of film stardom, thus arriving at what Horkheimer and Adorno call 'pseudo-indviduation' (1947 [1944]). This is underpinned by the same principle that, as artefacts of popular culture, film stars are presented to audiences in terms of what is individual, unique or different about them, but closer scrutiny reveals standardised commonalities from one example to the next, such as in their collective sporting of fashionable (for the time) hairstyles. Herein lies the link to the aforementioned example from contemporary celebrity culture, in that the persona of the celebrity lends a sense of individuality and differentiation to a standardised and mass produced product: in this case a commercial fragrance.

Illustrative of the extent to which this specific iteration of the pseudoindividuation of a mass market product is a phenomenon of celebrity in the contemporary era is the fact that upon its release, 'Lady Gaga Fame' was the latest in what had by then become an extremely long line of celebrity branded fragrances, some of the more well-known and notable of which included film and r'n'b pop star Jennifer Lopez's 'J-Lo Glow' in 2002, Sex and the City star Sarah Jessica Parker's 'Lovely' in 2005, pop mega-star Beyoncé's 'Heat' in 2010, and (former) footballer David Beckham's 'Homme by David Beckham' in 2011. One reason for the 
emergence of this trend for celebrity branded fragrances is that the practice of celebrity has become highly entrepreneurial in the contemporary era. This is in line with the free market values of late capitalism and neoliberalism that have dominated economies, cultures and societies in recent decades. As Barron writes, "From the perspective of political economy, contemporary celebrity culture mirrors and exemplifies the mode of flexible accumulation which [David] Harvey argues capitalism has adopted from the 1980s onwards as celebrities spread out their earning potential and capitalize on their fame by establishing footholds in numerous industries." $(2015,61)$ Nowhere in contemporary celebrity culture can this be seen more vividly than in the phenomenon of the Kardashians (Scheiner McClain 2014) and all their celebrity affiliates whose dramatic rise to global cross-media dominance of the celebrity-scape, under the savvy management of family matriarch Kris Jenner, was enabled by the success of their initial foray into the world of celebrity media, the $E$ ! entertainment television channel reality show Keeping $U p$ With The Kardashians (2007-). From that point on, the Kardashian celebrity brand developed and expanded in ways not just symptomatic, but epitomic of so much of what is typical of celebrity in the contemporary era: it is entrepreneurial (at the time of writing the Kardashian/Jenner brand has a net worth of over $\$ 450$ million), it is diversified (across the television, fashion, fragrance, beauty and make-up industries, to name only some), it is mediated across platforms on a global scale and with the immediacy made possible by twenty-first century digital technologies (for example, at the time of writing Kim Kardashian alone has over 55 million Twitter followers), and it enables and/or enhances the celebrity status of others who 
harness its popular cultural cachet in order to bolster their own (such celebrities include but are not limited to Kanye West, a hip hop star in his own right, he has nonetheless harnessed the power of the Kardashian celebrity brand through his relationship with Kim; Lamar Odom - moderately famous in his own right as a basketball star he achieved global celebrity status through his relationship with Khloe Kardashian to the point that he topped the list of Google's most popular search terms for 2015; and Blac Chyna - again, moderately famous as a model she became a global celebrity via her relationship with Rob Kardashian in 2016). One of the clearest manifestations of the consistency of the Kardashian brand can be seen in their persistent alliteration of newly and ever emerging brand outputs using the letter K. Hence, their launch of a fashion line is branded the Kardashian Kollection. Celebrity scholars Sean Redmond and Su Holmes succinctly describe the phenomenon of celebrity in the current era, in short, as 'the contemporary state of being famous' $(2007,8)$. In this way, they gesture towards the fact that it is not fame itself that is novel in today's celebrity culture, but rather the forms it takes, the ways it which it manifests and circulates, and the manner and extent of its permeation of media content, platforms and landscapes. In his own explanation of the specificities that mark contemporary iterations of celebrity out from longer standing historical understandings of the term and the phenomenon, Graeme Turner, in his now canonical treatise on this topic, summarises the state of celebrity in early twentyfirst century media culture in the following way: 
The contemporary celebrity will usually have emerged from the sports or entertainment industries; they will be highly visible through the media; and their private lives will attract greater public interest than their professional lives. Unlike that of, say, public officials, the celebrity's fame does not necessarily depend on the position or achievements that gave them their prominence in the first instance. Rather, once they are established, their fame is likely to have outstripped the claims to prominence developed within that initial location. Indeed, the modern celebrity may claim no special achievements other than the attraction of public attention; think, for instance of the prominence gained for short, intense periods by the contestants on Big Brother or Survivor. As a result, and as the Big Brother example might suggest, most media pundits would argue that celebrities in the twenty first century excite a level of public interest that seems, for one reason or another, disproportionate. (Turner 2004, 4)

Turner thus points to the dramatic shift in audience focus to which the contemporary era - enabled by digital culture after the normalisation of Web 2.0 that has produced the skyrocketing levels of accessibility, visibility and speed of circulation to and of celebrity imagery and discourse - has given rise towards the celebrity's private person or authentic self, and away from public sphere activities and accomplishments. He also highlights the importance of newer media forms and 
genres such as reality television, and the part played by them in producing the multitude of subjectivities that sustain the contemporary celebrity media machine, as well as cognate phenomena such as the fleeting or ephemeral nature of celebrity in the contemporary era, and the intensity and scale of audience engagement with it. All of these things, among others, will be considered in this chapter that investigates trends, patterns and specificities of celebrity in the contemporary era.

Celebrity is of course not a phenomenon that is new to our cultures and societies, or in fact to our media cultures. But a paradigm shift has occurred whereby we now speak to the existence of our so-called "celebrity culture" as a matter of course. And it is the ubiquity of celebrity culture in the contemporary era that has made this possible. As Turner notes, "the pervasiveness of celebrity across the modern mass media... encourages us to think of it as a new development, rather than simply the extension of a longstanding condition. The exorbitance of celebrity's contemporary cultural visibility is [...] unprecedented, and the role that the celebrity plays across many aspects of the cultural field has... expanded and multiplied." $(2004,4)$ It is thus the cross-media expansion and intensification of latter-day celebrity and celebrity oriented media that Turner points to as a noteworthy development in contemporary popular culture. All the same, there is research-based evidence to suggest that media audiences' appetite for consuming celebrity discourse has indeed increased in the contemporary era. For example, illustrating the millennial uptick in celebrity media discourse, Anita Biressi and Heather Nunn cite Grame Turner, Frances Bonner and P. David Marshall's 1997 study of the turn towards celebrity culture in Australia, highlighting "the increase in celebrity 
coverage in a sample from print and television news media, popular magazines and daytime chat shows" and pointing to findings from their research study that demonstrate that this sample revealed "between two to three times more coverage of celebrities than 20 years before in all of these media products." (Biressi and Nunn 2007a, 136)

Such developments have not been welcomed by self-proclaimed cultural gatekeepers. Contemporary celebrity culture has been viewed by some critics through the lens of 'moral panic' about the media, wherein the sensibilities of dominant culture are seen to be under threat from a malign presence or development in the media, anxieties about which are escalated such that they reach the level of official and public discourse (Watson and Hill 2015, 191). An instructive example that illustrates this is the moralistic position adopted by the feature documentary film Starsuckers (dir. Chris Atkins, 2009), which sets about to explore the media's obsession with celebrity in the contemporary era, working from a set of assumptions that present this state of affairs from the outset as inherently socially destructive, culturally denigrating and ideologically insidious.

The film draws on a variety of academic ideas in its attempt to explain and account for some noteworthy phenomena prominent in contemporary celebrity culture, such as child stardom, the celebrity entourage, cultures of fandom in a technologised mediascape, the manufacture and saleability of celebrity gossip, the rise and influence of the public relations industries, and the relationship between celebrity and contemporary consumer culture. And it does so from a range of perspectives taken from schools of thought in fields spanning evolutionary 
anthropology, child psychology, the psychology of addiction, sociology, journalism studies, political economy and forensic psychiatry. But with its clear agenda to excoriate contemporary celebrity culture it steers quite clear of many media and cultural studies approaches that offer less straightforwardly condemnatory or pejorative readings of the relationship between celebrity and the experience of everyday life in twenty-first century society.

For this reason, the contemporaneous feature documentary Teenage Paparazzo (dir. Adrian Grenier, 2010) stands as an interesting counter example of a factual film that attempts to account for and understand some of the vagaries and particularities of contemporary celebrity culture, making use as it does so of theoretical tools from celebrity studies and beyond in attempting to answer the questions about celebrity in the contemporary era that it poses to itself and its audience. These include Horton and Wohl's theory of 'para-social interaction' (1956) and the para-social relationship to understand the unbalanced nature of the relationship between celebrities and their followers. And Jean Baudrillard's notion of 'hyperreality' (1988) to understand the inauthenticity of some of the versions of self that celebrities present for circulation in the media, distinctly and differently from what is alternatively presented as their ostensibly authentic self.

Broadly speaking, Teenage Paparazzo is about the nature of celebrity in the contemporary era; but specifically it is about the prominence of paparazzi photojournalism in contemporary celebrity culture, and the allure of this phenomenon both to followers of celebrity news and gossip, and to aspiring paparazzi such as the titular teenage paparazzo: 14-year-old (at the time of filming) 
Austin Visschedyck. More specifically, the film is about the unlikely friendship that ensues between filmmaker Grenier and Visschedyck after Grenier sets out to investigate how the boy's life as a paparazzo came about, the appeal of such proximity to celebrity, and the nature of intensified celebrity culture in the twentyfirst century.

Grenier is himself a well-known celebrity, best known for being the star (both diegetically and extra-diegetically) of the HBO dramedy series Entourage (2004-2011), which remains one of the richest and most illustrative media fictions of millennial media culture to confront, depict and attempt to deal with some of the features of present day celebrity in a narrative that was directly premised on doing so. Entourage followed the professional rise to prominence and everyday life as a twenty-first century Los Angeles celebrity of Vincent Chase (Grenier), and his cadre of hangers-on, enablers and (in some cases) sycophants - the 'entourage' of the film's title. The phenomenon of the 'entourage' is another noteworthy feature of celebrity in the contemporary era, and has been usefully succinctly described and defined as a "social hierarchy based around your proximity to anyone well known" (Starsuckers, 2009) Correspondingly, one of the most interesting things about Entourage was the light it shed (albeit fictionally) on the operations of the celebrity public relations industries via its explorations of figures such as celebrities' agents, managers, publicists and promoters, and the business practices and logics that pertain to the experience of being a celebrity in the twenty-first century.

Joaquín Phoenix is another contemporary celebrity who, in collaboration with fellow celebrity and filmmaker Casey Affleck, has, like Grenier, made use of the 
media platform of feature documentary in order to attempt to make a self-reflexive intervention into the status quo of his own place within the Hollywood celebrity machine. As he avers at the outset of I'm Still Here (dir. Casey Affleck, 2010) "I don't want to play the character of Joaquín any more." The character he is here referring to was cemented by the persona he had built up over time playing roles defined by their intensity and emotional complexity, most notably his Oscar nominated performance as iconic country singer Johnny Cash in the biopic Walk the Line (dir. James Mangold, 2005), and the misconceptions this produced in the celebrity mediascape about his ostensibly authentic self.

In 2008 Phoenix and Affleck colluded to bait the celebrity media machine and its audience in contriving and staging a hoax 'celebrity trainwreck' (Holmes and Negra 2011) centred on Phoenix, his ostensible retirement from acting, his abortive attempt to forge a new career for himself as a recording artist in the hip hop genre, and the apparent unravelling of his mental health and emotional stability, seemingly as a result of the pressures of fame to which he had been subjected as a celebrity in the twenty-first century. Phoenix's biggest success in creating a 'celebrity flashpoint' (Turner, Bonner and Marshall, 2000) from his efforts to publicly deconstruct his own persona during this period came following an appearance on the Late Show with David Letterman in February 2009. In his interview with Letterman, which subsequently went viral online, the star's behaviour, demeanour and appearance were noticeably out of character as he self-presented as eccentric, troubled and misanthropic to the visibly bewildered but nonplussed television chat show host. Having said this, there had, by this point, already been a great deal of speculation in 
the celebrity news media and beyond that Phoenix's retirement and bizarre behaviour in public were indeed, as transpired to the the case, a hoax, in service to this public commentary on some of the absurdities and excesses of contemporary celebrity culture, which was subsequently offered up by their completed mockumentary.

There is a wide range of variables and contributing factors that interoperate to produce contemporary media cultures that are overwhelmed by celebrity as a discursive category, as a commercial commodity and as an object of consumption. And this can be attributed in part to some of the following things: the mass distribution of popular culture, media forms and artefacts to which the online environment of the contemporary era has given rise; twenty-first century technological advances that have changed the nature of visual and print media culture and the speed at which it circulates; the steady increase in the significance and influence of public relations and promotions to the cultural industries; and the widened scope of possibility for the trans-media saturation of celebrity oriented fare that has come about as a result of 'media convergence.' (Jenkins 2001) This, as Marcel Danesi argues, has seen 'the erosion of traditional distinctions among media due to concentration of ownership, globalization, and audience fragmentation; the process by which formerly separate technologies such as television and the telephone are brought together by a common technological base (digitization) or a common industrial strategy.' $(2008,290)$.

Cultural theorist Daniel Boorstin was prescient about the mediation of celebrity in the contemporary era when he theorised what he termed the 'pseudo- 
event' (1962) as 'an event planned and staged entirely for the media, which accrues significance through the scale of its media coverage rather than through any more disinterested assessment of its importance.' (Turner 2004, 5) Where the focus of attention in this scenario is the figure of the celebrity, the logical progression is thus, as indicated above, to the 'human pseudo-event,' (Turner, Bonner and Marshall 2000, 3-5). This kind of event, in line with some of what is described above about the production of I' $m$ Still Here, is similarly 'fabricated for the media and evaluated in terms of the scale and effectiveness of [its] media visibility.' (Turner 2004, 5)

More noteworthy instances of this from early twenty-first century celebrity culture include the respectively global media circuses that accompanied, for example, pop singer Justin Timberlake's onstage exposure of fellow singing star Janet Jackson's breast, and the event status accorded to her brother, pop star Michael Jackson's press conference which he had called for in order to announce his then forthcoming live shows in London. The former incident took place on $1^{\text {st }}$ February 2004 as part of the half-time show at that year's Superbowl - the biggest media event on the American football calendar. During their duo performance of Timberlake's hit 'Rock Your Body,' and at the point at which he delivered the lyric "I'm gonna have you naked by the end of this song," he ripped off part of Jackson's costume to briefly expose her right breast, part of which was concealed by a carefully placed piece of jewellery, cementing the assumption widespread at the time - that this had been a contrived and choreographed part of their act. The flashpoint that ensued from the media coverage that this stagemanaged event generated caused the phrase 'wardrobe malfunction' to enter the 
popular cultural lexicon to a level of normalisation that has transcended its original context; while the desire for instant access to and the repeatability of the video clip that depicted this moment is alleged to have inspired PayPal worker Jawed Karim to collaborate with colleagues to enable this, and thereafter to create and found the streamed video platform YouTube (Landau 2016, 51), a paradigm-shifting development in contemporary celebrity culture in many ways, and for a number of reasons. For example, as Sean Redmond writes, in reference to part of what has been game-changing about the interventions made in audiences experiences of celebrity by platforms such as YouTube: "The modern electronic media present and re-present the different phases that a celebrity may have gone through, through the way digital data, mobile platforms and cloud servers hold these moments in time in parallel and multi-temporal streams." ( $p$ 119) Redmond offers up the example of Miley Cyrus, who in this way exists in media culture simultaneously as a Disney child star, a tween culture icon, and a full-fledged adult pop star with a number of different iterative personae, thanks in part to the normalisation of digital media and of users' proclivities for platforms such as YouTube.

Returning to the aformentioned examples of so-called 'human pseudoevents', when Michael Jackson called a pre-arranged press conference in March 2009, the world's media and two thousand of Jackson's fans gathered in London at the Grand Concourse of the 02 concert arena to hear him announce a series of forthcoming dates. Footage of the press conference then saturated the mainstream news media and beyond on a global scale, ostensibly affording major world event status to Jackson's announcement. The spectacle of the media circus attendant to 
this contrived publicity event thus constitutes both 'pseudo-event' status, according to Boorstin's characterisation of the phenomenon; while the enormity of Jackson's public profile was such that the event (bolstered of course by the baggage carried by the longer history of his stardom and celebrity) afforded him the status of 'human pseudo-event.'

Notwithstanding the above stated importance to celebrity in the contemporary era of agents, managers, publicists and other kinds of public relations personnel, all of who play concrete roles in staging and managing these kinds of 'human pseudo-events,' there are nonetheless instances, albeit unusual ones, of celebrity events that cannot (in the first instance) be contrived, and cannot be predicted. Turner, Bonner and Marshall refer to such phenomena as "unpredictable eruptive events which suddenly [break] free of this form of management to become 'real' or uncontrolled events - for many, genuinely moving events - within our everyday lives.' $(2000,4)$ And here we arrive at the cognate notion of what they call the celebrity 'flashpoint,' explaining that '[i]ncreasingly, we encounter 'flashpoints' in contemporary culture, where a particular celebrity completely dominates media coverage, producing an excessively focused global public.' $(2000,3)$

As a pertinent, illustrative and instructive example, they point to the death on $31^{\text {st }}$ August 1997 of Diana Princess of Wales as one such flashpoint. As the authors explain:

the story's exorbitant visibility broke out of all the available classifications. It was simply uncontainable as news, as obituary, as 
identity politics, as entertainment, as myth or narrative, or as gossip. It dominated the 'quality' newspapers as well as the massmarket magazines and tabloids. Through all these avenues, the images which had created Diana's highly public life - the cover girl, the tabloid telephoto revelations, the official royal video footage, the romances - were replayed and reinterpreted. (2000, 3; see also Turnock 2000, Shome 2014 and Schwartz 2015)

The global media phenomenon that ensued in the aftermath of Diana's death is thus useful in applying and understanding the concept of the celebrity 'flashpoint.' Moreover, the mediated spectacles attendant to the sudden or (relatively) unexpected deaths of extremely high profile celebrities often epitomise this concept in a number of ways, including the 'exorbitant visibility' of the event in the public sphere; its 'uncontainability' as a news story; and its pervasion of both 'quality' publications and 'mass-market magazines and tabloids,' not to mention the immeasurable multiplicity of online news and gossip outlets. Thinking about more recent examples than Diana Princess of Wales, the media responses to deaths of Michael Jackson in June 2009 (before he had the opportunity to play any of the aforementioned concert dates) and Amy Winehouse in July 2011 both fit this model well.

These are just some of the major claims about celebrity in the contemporary era that have been made by scholars from across a number of disciplines, and by just some of the key contributors to this field of study. There are of course a number 
of futher key developments in cultures of celebrity that have informed the ever shifting cultural terrain through which contemporary celebrity discourse circulates in the digital and online era, and the necessity of negotiating discourses of authenticity around celebrities and their public identities is one other particularly noteworthy aspect of cultures of celebrity in the contemporary era.

Promises of (mediated, often disingenuously self-presenting as unmediated) access to the ostensibly 'true' selves and identities of celebrities have intensified alongside the early twenty-first century proliferation of the tabloid, reality and scandal forms of media that permeate contemporary popular culture. As well the changing nature of the relationship between celebrities and consumers of popular culture that has been brought about by the global normalisation of online social media and networks. As Biressi and Nunn write, "the discourse of self-disclosure and authenticity enabled by [then] new television formats such as docu-soaps, reality TV and lifestyle programming... allow ordinary people a narrative of selfimprovement and empowerment via personal self-disclosure and revelation of one's authentic self." (2007a, 138)

This concern with authenticity speaks to notion that the celebrity persona is a highly constructed mediation. And thus that it is inauthentic as a presentation of self, as well as increasing audience awareness of this. Hence, as Biressi and Nunn go on to highlight, where there is marked public interest in celebrity individuals with noticeably high levels of constructed artifice and with inauthentic personae, it 'is aroused by the desire to penetrate (through media coverage) that construction and gain access to some essential truth about that celebrity' $(2007 \mathrm{a}, 138)$. 
Another structuring discourse of celebrity in the contemporary era is that of democratisation (Andrejevic 2002, 268) - the idea that developments in latter day celebrity culture have produced a more level playing field that has increased the numbers of ways and means by which ostensibly ordinary individuals might attain celebrity status, heretofore the preserve of elites of different kinds. Biressi and Nunn refer to this shift as representing a 'kind of democratisation of the public sphere' $(2007 a, 138)$. We can thus understand this both in terms of the supposedly democratised access to celebrity status that such developments have heralded for aspirant celebrities, as well as in terms of increased agency on the part of media audiences, users and consumers to decide which individuals to single out for the kind of special attention germane to celebrity status, and to effect their elevation to celebrity, whether in cahoots with the cultural industries and their economic interests, or independently of them. As Biressi and Nunn explain further: 'Some critics argue that the new electronic media have enhanced both the individual's and the audience's ability to decide who should become a celebrity. Reality television programmes such as Big Brother and The X-Factor enable the public's direct vote for their winning aspirant celebrity.' $(2007 \mathrm{a}, 138)$

Arguably no media flashpoint did more to initiate a cultural shift toward the above mentioned 'tabloid culture' (Glynn 2000; Biressi and Nunn 2007) that has come to modally dominate the mediation of early twenty-first century celebrity than did the widespread and interminable mediation of the arrest, prosecution and trial of former American football star and film and television personality OJ Simpson in the mid-1990s (Glynn 2000; 2007). This became what cultural theorist Douglas 
Kellner termed a 'mega-spectacle' (2003) and signalled an important shift in media culture towards vis-a-vis the discursive prominence of celebrity and concomitantly the modal dominace of tabloid. According to Kellner the media circus and celebrity flashpoint that was the 0J Simpson trial heralded a transformation in media cultures of current affairs reportage in that it prompted a shift from 'news' to 'infotainment' $(2003,96)$ as it was broadcast live and daily on television platforms such as CNN, which was and is ostensibly a news channel, and $E$ ! which was and is ostensibly an entertainment channel (Barron 2015, 166). As Kellner writes, significantly the 0J Simpson event was also "a celebrity spectacle... with the tabloids and mainstream media alike focused on every detail of Simpson's life and the coverage creating new celebrities with every twist and turn of the investigation and trial." $(2003,99)$ These included witnesses (e.g. Brian Kato Kaelin, Simpson's neighbour, who became an actor and personality on US radio and TV), members of the judiciary (e.g. Judge Lance Ito, defense attorney Johnny Cochrane, and prosecutor Marcia Clark, each of who became household names and objects of media scrutiny in the US tabloids and beyond), and friends and family of the relevant parties (e.g. Robert Kardashian, whose friendship with OJ Simpson gave his family exposure to celebrities and their lifestyles, and was arguably the catalyst for the elevation of his family to global celebrity status, albeit long after his death in 2003).

Su Holmes and Diane Negra point to the mid-2000s as another important turning point moment for contemporary celebrity culture in that it gave rise to ' $\mathrm{a}$ period of highly discursive activity, across a range of media platforms, regarding the figure of the so-called female celebrity "trainwreck"' $(2008,2)$, wherein the celebrity 
gossip media machine and its audiences take and intense and prurient interest in observing and documenting the decline (i.e. in physical or mental/emotion health and stability, in financial solvency, in popularity, etc.) and public fall from grace of a heretofore admired or revered or popular female celebrity. Emphasising the extent to which they view this phenomenon as a markedly gendered one, they point to the death of Hollywood star Heath Ledger in 2008 and the suicide attempt made by fellow Hollywood star Owen Wilson in 2007 as counterpoint examples that illustrate the relative restraint with which male celebrities breakdowns are covered in the media, and the relative dignity afforded to their ordeals in this coverage. This is especially apparent when they are compared and constrasted with equivalent coverage of troubled periods for female celebrities like Britney Spears, Lindsay Lohan, Paris Hilton, Amy Winehouse, Jessica Simpson, Miley Cyrus and Amanda Bynes. Pop star Britney Spears' publicly mediated meltdown, which reached its peak in the celebrity gossip media when she was filmed and photographed having her head shaved in February 2007 (Luckett 2010), is one of the better known examples of the phenomenon of the female celebrity trainwreck. Asif Kapadia's documentary biopic Amy (2015) charts the process of celebritisation of the late pop star Amy Winehouse that accompanied the release and success of her Back to Black album in 2006. This saw her increasingly subject to intense scrutiny by the celebrity gossip media, tabloid press and paparazzi photographers as her success as a recording artist and perfomer increased, and her mental health, emotional stability and general well-being declined dramatically as her substance abuse (in her case both alcohol and drugs) intensified, and she was forced to live her personal life with her 
husband Blake Fielder-Civil in the public eye. All of this, as is well known, ultimately culminated in her death from alcohol poisoning in 2011 at the age of 27, and raised a number of questions in the popular commentariat and beyond about what is at stake and for who in the operations and practices of the celebrity gossip oriented media industries, and the pitfalls of intensified fame in contemporary celebrity culture.

Graeme Turner points to another key development in contemporary celebrity culture that he characterises in terms of what he calls the 'demotic turn' (2010), whereby ever increasing numbers and proportions of ostensibly heretofore 'ordinary' people are equipped with different kinds of means, motivations and opportunities to attain celebrity status, and to participate as agents in as well as consumers of celebrity culture. Some of the arenas that he points to by way of illustration and elaboration include the latter day proliferation of things like reality TV (especially competitive forms of reality TV that consciously invest in their own manufacture of new celebrity figures in arenas ranging from pop music, i.e, the $X$ Factor, Idol and Voice franchises, to the business world i.e. the Apprentice franchises, and cheffing, cooking and baking, i.e. the Masterchef, Bake-Off and Come Dine With Me franchises), and online platforms (especially streaming sites like YouTube and Daily Motion, which have given rise to the celebrity of individuals ranging from pop star Justin Bieber to fashion and beauty vlogger Zoella).

The rise to prominence of reality television as a normalised and abundantly produced form of media has, over time, revealed itself to have been a highly significant development in enabling particular formations of contemporary celebrity 
to flourish in the contemporary media environment. On the one hand, it has provided innumerable avenues of possibility for aspirant celebrities from amongst the rank and file of so-called 'ordinary' people, for who fame is no longer something out of reach reserved only for the extraordinary, the exceptional, the privileged, the uniquely talented or the singularly lucky, but rather appears attainable and realisable as a life goal, achievable by potentially anyone. While on the other it has provided equally numerous opportunities for pre-existing celebrities to adapt to the changing requirements of celebrity culture by providing increased access to their ostensibly 'authentic' selves via reality television formats, capitalising on new forms of celebrity currency to enhance their media visibility, and often reviving moribund careers by using the intimacy of reality formats to make the judicious transition from distant star to accessible celebrity that the contemporary era requires of those who would ensure that their public profiles experience longevity and operate with a wide reach in twenty-first century media culture. With regard to the former, the early years of the kinds of docu-dramas/soaps that would quickly evolve into what we now call reality television, produced (relatively fleeting) celebrity status for heretofore 'ordinary' members of the public like driving student Maureen Rees who emerged as the star of the BBC's Driving School (1997) and Aeroflot Airlines ground services manager Jeremy Spake who emerged as the star of the BBC's Airport (19962008).

Su Holmes acknowledges and engages with the 'cultural decline' versus 'populist democracy' (Evans) debate around which discussions of the rise to prominence of ostensibly 'ordinary' people in contemporary cultures of fame have 
been polarised to discuss the media phenomenon that arose around the rapid ascent to celebrity status of Susan Boyle in $2009(2010,74)$. Boyle was then an unemployed 47-year-old woman from the city of Glasgow in the UK, who was instantly propelled to celebrity status following her first audition on reality TV talent show Britain's Got Talent (2007-). Upon reaching the final, she lost out to another contestant on the night, but nonetheless went on to find enormous commercial success as a singer, recording artist and celebrity. The same series was similarly responsible for the comparable fame of popular/ist opera singer Paul Potts, who even went on to become the subject of a biopic, One Chance (Dir. David Frankel, 2013), which narrates the story of his lifelong quest for the niche stardom offered by singing success in the world of opera and his eventual rapid rise to celebrity status as a reality tv singing sensation, and in which he was played by fellow celebrity James Corden.

Reality television has also been a efficacious platform for enabling the transition to mainstream celebrity status for performance artists from groups that have heretofore been marginalised from the mainstream, their fame restricted to the sub-cultural niches afforded by their respective communities. Arguably the most vivid example can be seen in the widespread appeal across demographic groups of RuPaul's Drag Race (2009-), which has, for better or worse dependent on your viewpoint, harnessed the currency of reality television to re-situate the historically sub-cultural performance art of drag queens from the margins to the mainstream, generating bona fide media celebrity status for high profile and popular performers such as season six winner Bianca Del Rio (the drag persona of performer Roy 
Haylock), who parlayed her elevated celebrity status into further opportunities, going on to star in the crowd-funded film Hurricane Bianca (dir. Matt Kugelman, 2016), alongside many of her Drag Race contemporaries and a number of prominent figures from wider celebrity culture.

The normalisation of social media in the online era has in some ways fundamentally changed the nature of the relationship between celebrities and their fans, and for celebrity studies it has forced a re-evaluation, reconceptualisation and critical augmentation of Horton and Wohl's notion of 'parasocial interaction' (1956). A particularly noteworthy example can be seen in the spectacle that emerged out of events surrounding what was initially termed in U.S. news media reportage as the 'Hollywood Hills Burglaries', later dubbed 'The Bling Ring' in reference to the luxury personal adornments and attire taken by the eponymous group of youths during their stealing spree at the homes of Los Angeles based celebrities like Paris Hilton, Lindsay Lohan and Rachel Bilson, to name only some. This phenomenon was subsequently reported in the Vanity Fair article 'The Suspects Wore Louboutins' (Sales 2010), the publication of which inspired these events to be dramatized in the film The Bling Ring (dir. Sofia Coppola 2013).

The thematisation of celebrity and cultures of fame and notoriety has been a recurring authorial motif of Coppola's filmmaking. Most of her films, to varying extents and in a numbe of ways offer differing meta-commentaries on various aspects of, to re-invoke Holmes and Redmond's useful phrase again, 'the contemporary state of being famous'. But The Bling Ring wears its purposeful engagement with celebrity in the contemporary era plainly on its sleeve from the 
outset, as the opening sequence intercuts between shots of the eponymous group of privileged white youths narcistically documenting themselves and their social lives on social media sites like Facebook via a succession of interminable selfies and status updates, and celebrity gossip tabloid news footage of individuals like the aforementioned Hilton, Lohan and Bilson. From the outset the film thus invites the audience to draw a link between the group's narcissistic behaviour, enabled by a combination of socio-economic privilege and social media, their obsession with celebrities and the sense of intimacy that they feel (consciously or otherwise with them), and their criminally anti-social behaviour. The film even goes so far as to blur the lines between reality, it's mediation, and the mediation of its mediation in the fact that, for example, a scene that recreates the group's invasion of the home of Paris Hilton, was filmed in Hilton's actual home, where the events on which the scene is based actually took place.

In some ways the film echoes wider society and culture in falling back on familiar discourses that view fan/follower fascination with contemporary celebrity pejoratively, particularly via the character of Nicki (Emma Watson) who is constructed and depicted as a classic narcissist, in line with celebrity theorist Chris Rojek's claims that the inflation of celebrity has produced a spike in media users who display the symptoms of narcissitic personality disorder, who hero worship celebrities and their lifestyles, and who stalk celebrities (2012, 35-50), all three of which are applicable to Nicki as she has been rendered in Coppola's film adaptation of these events. Nicki is thus unsurprisingly shown to take every opportunity that the case presents her with to attain celebrity status for herself, going so far as to 
express delusional misconceptions about the nature and level of her celebrity status in the aftermath of the group's apprehension by the LAPD that place her as a celebrity humanitarian alongside the likes of Angelina Jolie. Significantly Jolie is offered up by Nicki's mother as a role model figure on these grounds, despite the fact that Nicki is unable to see the worth of Jolie's celebrity beyond her "hot bod". The film as a whole, along with the Vanity Fair article that inspired it, is thus premised on the notion that the digital age fosters a relationship between millennial media users and celebrity culture and lifestyles that can and does produce obsessive, anti-social and even in this case criminal behaviour.

A useful counterpoint to these kinds of fairly straightforwardly negative assumptions about this relationship is offered up by the findings of work undertaken by scholars Kimberley Allen, Laura Harvey and Heather Mendick from their recent (at the time of writing) 'Celeb Youth U.K.' research project. Allen et al conducted ethnographic research exploring the relationship between young people's engagement with contemporary celebrity culture and their aspirations for their own futures. Their findings served to debunk a lot of the assumptions that tend to be made about the nature and effects of this engagement, and propagated in highprofile and potentially high-impact spheres - assumptions like the idea that young people's aspirations derive from their engagement with celebrity culture and include "to get rich quick" (Allen, Harvey and Mendick 2014).

Another phenomenon germane to celebrity in the contemporary era is the arguably niche form of fame termed by Terri Senft as 'micro-celebrity' (2008, 25; see also Marwick 2016 for a discussion of how this kind of celebrity operates in 
social media spheres), most often seen in instances whereby individuals develop celebrity status in specific online spheres and with correspondingly niche but dedicated followings. As Senft writes, 'While the Web can be used as a platform for traditional celebrity... it cannot create old-fashioned stars of its own. Instead, the web provides the conditions for what I call "micro-celebrity" (Senft 2008, 25). For examples of such instances of this so-called 'micro-celebrity' we might look to celebrity YouTubers, or 'weblebrities' as they are also known, like the six individuals profiled for the feature documentary Butterflies (dir. Esther Brymova, 2009), one of who, Lucas Cruikshank, had his YouTube persona 'Fred' adapted to the context of a mainstream made-for-television feature film (which received a theatrical release in the UK) in Fred: The Movie (dir. Clay Weiner, 2010). Writing in 2008, Senft vividly illustrated the extent to which the celebrity of indivduals like these should, in the main (Cruikshank is a noteworthy exception) be considered niche when she averred that 'in terms of both raw audience numbers and economic gain, Web stars pale in comparison to even 'D' list performers in the film, television and music industries.' (25)

Contemporary celebrity culture has also seen some noteworthy developments in the area of celebrity coupledom, kinship, dynatsties and intimacies. As Shelley Cobb and Neil Ewen highlight in their prescient anthology First Comes Love, the tabloid and gossip media omnipresence of the celebrity portmanteau is a signature feature of the fascination with and discursive prominence of coupledom in celebrity culture of the contemporary era. The term 'portmanteau' refers to the conflation of two distinct terms or epithets to create one 
new one which has acquired new and distinct meaning in this act of conflation. Hence, where contemporary era celebrities are concerned, the new meaning carried by the portmanteau tends, in the main to signify romantic partnership and/or long term coupledom, e.g. 'Brangelina' (Brad Pitt and Angelina Jolie) TomKat (Tom Cruise and Katie Holmes), Bennifer (Ben Affleck and Jennifer Lopez/Garner) Robsten (Robert Pattinson and Kristen Stewart) Kimye (Kim Kardashian and Kanye West) and Hiddleswift (Tom Hiddleston and Taylor Swift) to name only some of those that have to date been the most ubiquitous in media discourse (Díaz 2015; Negra 2015). But media and audience attention to the kinship structures of contemporary celebrities has not been limited to he romantic partnership of couples; in some noteworthy cases the celebrity of larger family units has operated and signified under the banner of what Rachel Dwyer, referring to the multigenerational Bollywood stardom of Indian cinema A-listers the Kapoors, has termed 'dynastic stardom' (2015). In contemporary Anglophone cultures of cross-media celebrity, particularly prominent examples include The Kardashians, the Beckhams, and the Smiths, to name only some.

The figure of the celebrity philanthropist and the celebrity humanitarian has almost emerged with heretofore unprecedented levels of discursive prominence in contemporary culture (see Wilson 2014 who theorises this phenomenon in terms of its status as a form of 'global citizenship'). Contemporary era flashpoints in the mediation of celebrity humanitarianism have included those that have emerged from, for example, the decision by Hollywood actors Angelina Jolie and Brad Pitt that their daughter Shiloh would be born in Namibia, which she was in 2006; and 
pop icon Madonna's decision to adopt baby David Banda (amidst considerable controversy) in Malawi in 2006. In both cases, these celebrity flashpoints both followed and preceded periods of time spent by the celebrities in question engaged in humanitarian awareness raising activities and acts of philanthropy in these places. Other examples include George Clooney's activities in Darfur, specifically the celebrity flashpoint that arose from his participation in the Save Darfur Coalition Press Conference on 15th December 2006; Sean Penn's attraction of media attention to his relief activities in New Orleans after Hurricane Katrina in 2005 and then later after the devastating earthquake in Haiti in 2010. The power of celebrity was also harnessed in ostensible service to the causes of global humanitarianism via the worldwide mediation of relief concerts Live Aid, Live 8 and in via the high media profile of the Make Poverty History coalition, and the Not On Our Watch Charity.

The noteworthy features of celebrity in the contemporary era are too numerous and too far reaching to be fully accounted for in a chapter of this length. And there remains much to say and think about that it is beyond the scope of this chapter to to be able to address. For example, the increased visibility and cultural prominence in contemporary media culture of older celebrities (see Jermyn 2012), of 'celesbians' (see Heller 2014; Cobb 2015), 'gal pals' (see McBean), and transgender/non-cis gender celebrities (see Brady 2016), and of celebrity feminism/feminist celebrities (see Hamad and Taylor 2015; Taylor 2017). Celebrity may be far from a new phenomenon in and of itself, but as I hope to have demonstrated in this chapter, there are many new and recent celebrity phenomena 
investigation of which sheds light on much that is noteworthy about contemporary culture and the media in the twenty-first century.

\section{References}

Adorno TW (1990 [1941]) On popular music. In: Frith S and Godwin A (eds) On record: Rock, pop and the written word. London: Routledge.

Airport (1996-2008). BBC.

Allen K, Harvey L and Mendick H (2014) Mythbusting on celebrity youth and aspirations. CelebYouth.org. Available at: http://celebyouth.org/mythbusting/ [accesed 17th February 2017].

Amy (2015) Dir. Asif Kapadia. Film 4 and On The Corner Films.

Andrejevic M (2002) The kinder, gentler gaze of Big Brother reality TV in the era of digital capitalism. New Media \& Society 4(2): 251-170.

Barron L (2015) Celebrity cultures: An introduction. London: Sage. 
Baudrillard J (1988) Simulacra and Simulation. In: Poster M (ed) Selected writings. Stanford: Stanford University Press, pp. 166-184.

Biressi A and Nunn H (2007a) Section 4. celebrity. In: Biressi A and Nunn H (eds) The tabloid culture reader. Maidenhead and New York: McGraw Hill/Open University Press, pp. 135-140.

Biressi A and Nunn H (2007b) The especially remarkable celebrity and social mobility in reality TV. In: Biressi A and Nunn H (eds) The tabloid culture reader. Maidenhead and New York: McGraw Hill/Open University Press, pp. 149162.

Bling Ring, The (2013) Dir. Sofia Coppola. Dick Clark Productions and Silver Screen Pictures.

Boorstin D (1961) The image: A guide to pseudo-events in America. New York: Vintage.

Brady, A (2016) Keeping away from the Kardashians: Celebrity worth and the remasculinising of Caitlyn Jenner. Celebrity Studies 7(1): 115-118.

Britain's Got Talent (2007-). ITV. Talkback Thames/Thames and Syco. 
Butterflies (2009) Dir. Brymova E.

Cobb S (2015) Ellen and Portia's wedding: The politics of same-sex marriage and celesbianism. In: Cobb S and Ewen N (eds) First comes love: Power couples, celebrity kinship and cultural politics. New York and London: Bloomsbury, pp. 211-234.

Danesi M (2008) Popular culture: Introductory perspectives. Lanham, Maryland: Rowman \& Littlefield.

Díaz V (2015) ‘Brad \& Angelina: And now ...Brangelina!’': A socio-cultural analysis of blended celebrity couple names. In: Cobb S and Ewen N (eds) First comes love: Power couples, celebrity kinship and cultural politics. New York and London: Bloomsbury, pp. 275-294.

Driving School (1997). BBC.

Dwyer R (2015) A star is born? Rishi Kapoor and dynastic charisma. In: Cobb S and Ewen N (eds)First comes love: Power couples, celebrity kinship and cultural politics. New York and London: Bloomsbury, pp. 96-115.

Entourage (2004-2011). HBO. Leverage Management/Closes to the Hole Productions. 
Evans J (2005) Celebrity, media, history. In: Evans J and Hesmondhalgh D

(eds) Understanding media: Inside celebrity. Buckinghamshire: Open University

Press, pp. 7-32.

Fred: The Movie (2010) Dir. Weiner C. Derf Films and Varsity Pictures.

Glynn K (2000) Tabloid culture: Trash taste, popular power, and the transformation of American television. Durham: Duke University Press.

Glynn K (2007) And postmodern justice for all: The tabloidization of OJ Simpson. In: Biressi A and Nunn H (eds) The tabloid culture reader. Maidenhead and New York: McGraw Hill/Open University Press, pp. 176-190.

Hamad H and Taylor A (2015) Introduction: feminism and contemporary celebrity culture. Celebrity Studies 6(1): 124-127.

Heller D (2014) Wrecked: Programming Celesbian Reality. In: Weber, BR (ed) Reality Gendervision. Durham and London: Duke University Press, pp. 123-146.

Hillyer M (2010) Underexposed overexposure: One Night in Paris. The Velvet Light Trap 65: 20-21. 
Holmes S (2010) Dreaming a dream: Susan Boyle and celebrity culture. The Velvet Light Trap 65: 74-76.

Holmes S and Negra D (2011) Introduction: In the limelight and under the microscope - the forms and functions of female celebrity. In: Negra D and Holmes S (eds) In the limelight and under the microscope: Forms and functions of female celebrity. New York and London: Continuum, pp. 1-16.

Horkheimer, M and Adorno TW (1947 [1944]). Dialectic of enlightenment. Querido: Amsterdam.

Horton D and Wohl RR (1956). Mass communication and para-social interaction: Observations on intimacy at a distance. Psychiatry 19: 215-29.

Hurricane Bianca (2016) Dir. Matt Kugelman. Wolfe Video.

I'm Still Here (2010). Dir. Casey Affleck. They Are Going to Kill Us Productions/Flemmy Productions.

Jenkins H (2001) Convergence? I diverge. Technology Review. Available at: http://web.mit.edu/cms/People/henry3/converge.pdf (accessed 14 August 2010). 
Jermyn D (2012) 'Get a life, ladies. Your old one is not coming back': Ageing, ageism and the lifespan of female celebrity. Celebrity Studies 3(1): 1-12.

Keeping Up With The Kardashians (2007-). E!. Ryan Seacrest

Productions/Bunim/Murray Productions.

Kellner D (2003) Media spectacle. London and New York: Routledge.

Landau N (2016) TV outside the box: Trailblazing in the digital television revolution. Abingdon and New York: Focal Press.

Luckett M (2010) Toxic: the implosion of Britney Spears's star image. The Velvet Light Trap 65: 39-41.

Marwick AE (2016) You may know me from YouTube: (micro-)celebrity in social media. In Marshall PD and Redmond S (eds) A companion to celebrity. John Wiley \& Son, pp. 333-350.

McBean S (2016) The 'gal pal epidemic'. Celebrity Studies 7(2): 282-284.

Negra D (2015) The making, unmaking and remaking of Robsten. In: Cobb S and Ewen N (eds) First comes love: Power couples, celebrity kinship and cultural politics. New York and London: Bloomsbury, pp. 313-330. 
One Chance (2012) Dir. David Frankel. Syco Entertainment.

Pramaggiore M and Negra D (2014) Keeping up with the aspirations: Commercial family values and the Kardashian brand. In: Weber, BR (ed) Reality Gendervision. Durham and London: Duke University Press, pp. 76-96.

Redmond, S (2014) Celebrity \& the media. Basingstoke and New York.

Redmond S and Holmes S (2007) Introduction: What's in a reader? In: Redmond S and Holmes S (eds) Stardom and celebrity: A reader. London and Thousand Oaks: Sage, pp. 1-12.

Rojek, C (2012) Fame attack: The inflation of celebrity and its consequences. London and New York: Bloomsbury Academic.

RuPaul's Drag Race (2009-). Logo/VH1.

Sales, Nancy Jo (2010) The suspects wore Louboutins. Vanity Fair. March. Available at: https://www.vanityfair.com/culture/2010/03/billionaire-girls-201003 [Accessed 10 April 2017]. 
Scheiner McClain A (2014) Keeping up the Kardashian brand: Celebrity, materialism and sexuality. Lanham, Maryland: Lexington Books.

Schwartz M (2015) Dead matter: The meaning of iconic corpses. Minneapolis: University of Minnesota Press.

Senft TM (2008) Camgirls: Celebrity \& community in the age of social networks. New York: Peter Lang.

Shome R (2014) Diana and beyond: White femininity, national identity, and contemporary media culture. Urbana, Chicago and Springfield: University of Illinois Press.

Starsuckers (2009) Dir. Atkins C. S2S Productions.

Taylor A (2017) Celebrity and the Feminist Blockbuster. Basingstoke and New York: Palgrave Macmillan.

Teenage Paparazzo (2010) Dir. Grenier A. Reckless Productions.

Turner G, Bonner F and Marshall PD (2000) Fame games: The production of celebrity in Australia.Cambridge: Cambridge University Press. 
Turner G (2004) Understanding celebrity. London and Thousand Oaks: Sage.

Turnock R (2000) Interpreting Diana: Television audiences and the death of a princess. London: BFI.

Watson J and Hill A (2015) Dictionary of media and communication studies. New York and London: Bloomsbury Academic.

Wilson JA (2014) Stardom, sentimental education, and the shaping of global citizens. Cinema Journal 53(2): 27-49. 